\title{
NACIONALNE STRATEGIJE IZOBRAŽEVANJA ODRASLIH ${ }^{1}$ \\ Strateški razvoj izobraževanja odraslih $v$ nekaterih evropskih državah
}

dr. Zoran

Jelenc

a mnoge dejavnosti, zlasti za tiste, ki se ponašajo z dolgo zgodovino svojega obstoja in razvoja, je samo po sebi umevno, da so si sčasoma oblikovale bolj ali manj opredeljene in jasne koncepcije za svojo dejavnost, bodisi celovito bodisi po posameznih področjih. Poleg potrebe po opredeljevanju dejavnosti, da bi tako laže razpoznavala in identificirala samo sebe, narekujejo takšno koncipiranje in opredeljevanje tudi povsem pragmatični razlogi, med njimi zlasti potreba po njenem sistemskem urejanju in pridobitvi ustreznega mesta v družbeno-razvojnih načrtih za razvoj in spodbujanje razvoja dejavnosti. V optimalnem primeru se države odločajo za izdelavo in sprejetje posebnih nacionalnih programov za razvoj posameznih dejavnosti.

Že po bolj sistematičnem pregledu razpoložljivih virov lahko dovolj zanesljivo ugotovimo, da je bilo v preteklosti konceptualizaciji izobraževanja odraslih in tudi andragogiki namenjene sorazmerno malo pozornosti, tako $\mathrm{v}$ sistemskih razvojnih dokumentih o vzgoji in izobraževanju kot tudi v stroki sami. Bistveno drugačno je stanje pri obravnavanju sistemov ali koncepcij šolskega začetnega (inicialnega) izobraževanja ali izobraževanja otrok in mladine na splošno. ${ }^{3}$
Ali je tako tudi pri izobraževanju odraslih kot dejavnosti in andragogiki kot znanstveni disciplini o izobraževanju odraslih? To vprašanje nas je posebej zanimalo $\mathrm{v}$ tem prispevku in $\mathrm{v}$ raziskavah, $\mathrm{v}$ katerih se $\mathrm{z}$ njim bolj poglobljeno ukvarjamo. ${ }^{2}$

Pri izobraževanju odraslih gre očitno za dejavnost, ki se sistemsko in konceptualno šele razvija, čeprav ji ne moremo odrekati dolge pojavnosti v vsakdanjem življenju in zgodovini človeštva. Celo temeljitejša, za večino strokovnjakov še kar sprejemljiva opredelitev izobraževanja odraslih je stara komaj dobrih dvajset let. Sprejemljiva pa je le zato, ker je zelo vseobsegajoča in skuša povezati različne možnosti izobraževanja odraslih, ne da bi jih postavljala $\mathrm{v}$ bolj opredeljen ali konsistenten sistem družbene ali strokovne dejavnosti. ${ }^{4}$

\section{RAZVOJ SISTEMSKEGA UREJANJA IN CELOVITIH NACIONALNIH PROGRAMOV ZA IZOBRAŽEVANJE ODRASLIH}

Ena zadnjih potrditev navedenih ugotovitev je študija, ki jo je po naročilu OECD opravil leta 1997 Kjell Rubenson in jo objavil z naslovom Adult Education and Training: The Poor Cousin (Rubenson, 1997). ${ }^{5}$ Glavno pozornost pri analizi je avtor namenil ugotavljanju položaja in vloge izobraževanja odraslih ${ }^{6} \mathrm{v}$ nacio- 
nalnih politikah vzgoje in izobraževanja, ki jih obravnava v okviru vseživljenjskega učenja.

Rubensonove analitične ugotovitve o navedenem položaju izobraževanja odraslih lahko na kratko strnemo v tri temeljne točke: ${ }^{7}$

- Izobraževanje odraslih v nacionalnih poročilih praviloma ni ustrezno opredeljeno in obravnavano. Njegovim področjem ali delom (na primer formalno, neformalno, javno, zasebno, splošno, poklicno, poljudno itn.) se ne namenja enaka pozornost ali se celo ne prepoznavajo kot enako pomembna področja izobraževanja odraslih; so celo primeri, ko se enačita ali zamenjujeta pojma vseživljenjsko učenje in izobraževanje odraslih.

- V nobenem poročilu ni glavnega poudarka na izobraževanju odraslih, praviloma pa mu ni namenjena zadostna ali enaka pozornost kot drugim, tradicionalno bolj obravnavanim področjem vzgoje in izobraževanja; to se zlasti kaže $v$ neenakosti pri njunem si-

$\checkmark$ nacionalnih strategijah izobraževanje odraslih še vedno ni zadovolivo opredeljeno. stemskem obravnavanju (na primer statistično spremljanje, raziskovanje, financiranje itn.).

- Niso opredeljene nacionalne politike glede izobraževanja odraslih, kolikor pa so, pa domala $v$ nobeni državi ni kohezivne politike za izobraževanje odraslih. To je razumljivo ob že navedeni ugotovitvi, da se izobraževanje odraslih praviloma ne dojema kot kohezivna celota.

Poleg navedenih kritičnih ugotovitev glede izobraževanja odraslih kaže omeniti tudi to, da $\mathrm{v}$ obravnavanih nacionalnih poročilih sodelujočih držav - v nasprotju s poudarjanjem pomembnosti načel in strategije vseživljenjskosti učenja -, v dokumentih, ki opredeljujejo nacionalne politike in tudi politike medvladnih organizacij, ni vseživljenjskosti uče- nja kot vodilnega načela vsega izobraževanja v konkretnih izpeljavah nacionalnih politik. Avtor označuje to ugotovitev kot povsem »šokantno« (N. d.: 12). Ena od mnogih priporočil in usmeritev, ki jih navaja $v$ svoji analizi in ki so zlasti pomembne za to, kar obravnavamo $\mathrm{v}$ tem prispevku, je ta, da bi bilo treba izobraževanje odraslih povezati $\mathrm{v}$ enoten, vseobsegajoč sistem (N. d.: 21, 22). Če želimo, da bi države oblikovale kohezivno politiko do izobraževanja odraslih kot celote, je takšna ugotovitev povsem logična.

Čeprav na opisani položaj izobraževanja odraslih $\mathrm{v}$ nacionalnih politikah gotovo zelo vpliva, da je dejavnost ali disciplina razmeroma mlada, je še mnogo drugih razlogov za to, objektivnih (obvladljivost sistema, financiranje, struktura upravljanja itn.) in tudi subjektivnih (predsodki, tradicija, počasno prilagajanje na nove razmere itn.), ki zavirajo poskuse celovite ali specifične konceptualizacije izobraževanja odraslih. Med njimi niso najmanj pomembna razhajanja med andragogi, ko gre za opredeljevanje možnosti, da bi pojmovali in obravnavali izobraževanje odraslih kot celovit sistem. Brez ambicije, da bi na tem mestu temeljito in poglobljeno obravnavali to vprašanje, ga le nekoliko osvetlimo s stališči znanih andragogov iz mednarodne raziskave, opravljene pred nekaj leti pri nas. ${ }^{8}$

Na vprašanje, ali pojmujejo izobraževanje odraslih kot celovit sistem ali ne, so nam vprašani - najbolj znani svetovni strokovnjaki za izobraževanje odraslih - odgovorili zelo različno. Njihove odgovore lahko (Jelenc, Krajnc, Svetina 1993: 295-298) na grobo razporedimo v tri skupine:

1. Tisti, ki kategorično zavračajo opredelitev, da je izobraževanje odraslih celovit (koherenten) sistem, saj menijo: da ga sestavljajo same različnosti (na primer različne institucije, cilji, potrebe, dejavnosti, področja dejavnosti, uporabniki, subjekti, ki sodelu- 
jejo pri njegovem organiziranju, načini organiziranosti in izpeljave, načini upravljanja in sistemske ureditve, sektorska pripadnost, koncepti in filozofije itn.); da ne sme pripadati nobeni strukturi, ker bi to ogrozilo njegovo neodvisnost; da ga označujeta izjemno hitra in dinamična rast ter gibkost in da je njegov razvoj težko predvideti; da njegov razvoj preveč določajo zgodovinske, geografske, kulturne in druge družbene značilnosti.

2. Tisti, ki niso kategorično zanikali ali pritrdili, bodisi da je bodisi da ni sistem, izražajo pomisleke: da je to je sistem, ki še ni dovolj razvit in se šele oblikuje; da ga še ne razumemo prav, saj je šele vizija, in da $\mathrm{v}$ praksi lahko prepoznamo le nekatere njegove prvine.

3. Avtorji, ki izobraževanje odraslih opredeljujejo kot celovit sistem, a ga dojemajo: kot sistem izrazito pluralistične narave $\mathrm{z}$ velikimi razlikami; kot področje, ki označuje izobraževalno dejavnost za določen del populacije in lahko pri tem najdemo podobnosti pri zvrsteh, oblikah, izvedbenih načinih, organiziranosti itn.; kot pojem in kot tak kot analizni produkt, ki daje vrsti na videz nepovezanih dejavnosti »intelektualno koherenco na ravni globlje strukture $\ll . ?$

Dvome ali pomisleke ter različna stališča glede teh ali onih značilnosti in razsežnosti izobraževanja odraslih, med temi tudi o možnostih koncipiranja in sistemskega urejanja izobraževanja odraslih, lahko tudi sicer pogosto najdemo bodisi v praksi bodisi v strokovnoteoretičnih virih. Pri tem niso izjema niti novejši, vsebinsko najbolj izpopolnjeni in na sodobnih spoznanjih temelječe leksikografske izdaje in priročniki (Titmus 1989a; Merriam/Cuningham, 1991; Tuijnman, 1996 itn.). Vzroki za to, da se izobraževanje odraslih ni moglo razviti $\mathrm{v}$ koherenten sistem in da ima pri tem še zdaj hude težave, so tudi v tem, da je pretežno nastajalo $\mathrm{v}$ praksi ter za prakso in se je tako moralo prilagajati trenutnim razmeram; tako tudi ni iskalo skupnih teoretičnih izhodišč in modelov, po katerih bi se ravnalo; do nedavna tudi še ni bilo posebnih programov za pridobitev andragoške izobrazbe (diplome); praznino, pomanjkanje andragoško usposobljenih strokovnih kadrov, so zapolnjevale druge stroke; posledica tega pa je bila, da so se vanj vnašale izkušnje iz drugih strok, dobre in slabe, in da je, čeprav je iz drugih strok prišlo marsikaj koristnega, posredno slabela koherentnost vede ali področja. To razmišljanje bi lahko še nadaljevali, vendar ga skrajšajmo s preskokom na specifične okoliščine, ki jih je s povečano intenziteto prinesel sedanji čas, to je obravnavanje izobraževanja odraslih v okviru vseživljenjskosti učenja.

\section{KONCEPCIJA O VSEŽIVLJENJSKOSTI UČENIA OMOGOČA IN ZAHTEVA SISTEMSKO UMESTITEV IZOBRAŽEVANJA ODRASLIH}

Ker to ni osrednja tema tega prispevka, bomo nastalo povezavo opredelili z nekaj posplošenimi, vendar za razumevanje bistva tega prispevka zelo temeljnimi tezami ali ugotovitvami, to so:

1. S konceptom vseživljenjskosti učenja je izobraževanje odraslih našlo praktično in, kar je še posebej pomembno, teoretično neizpodbojno utemeljitev za svoj obstoj, kot področje dejavnosti in tudi kot veda v družini vzgojno-izobraževalnih ved. Dejstvo je, kot je ugotovil že Titmus (1889: 382), da je načelo vseživljenjskosti izobraževanja

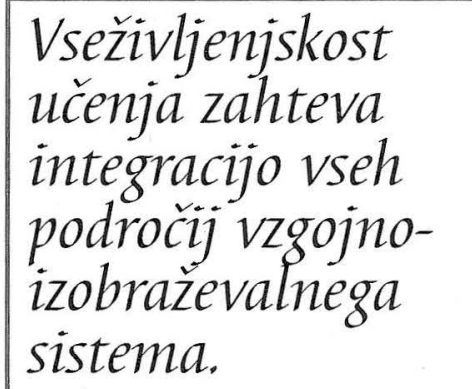
sprožilo potrebo po integraciji vseh področij vzgojno-izobraževalnega sistema (vertikalno in horizontalno) in da je to pospeši- 


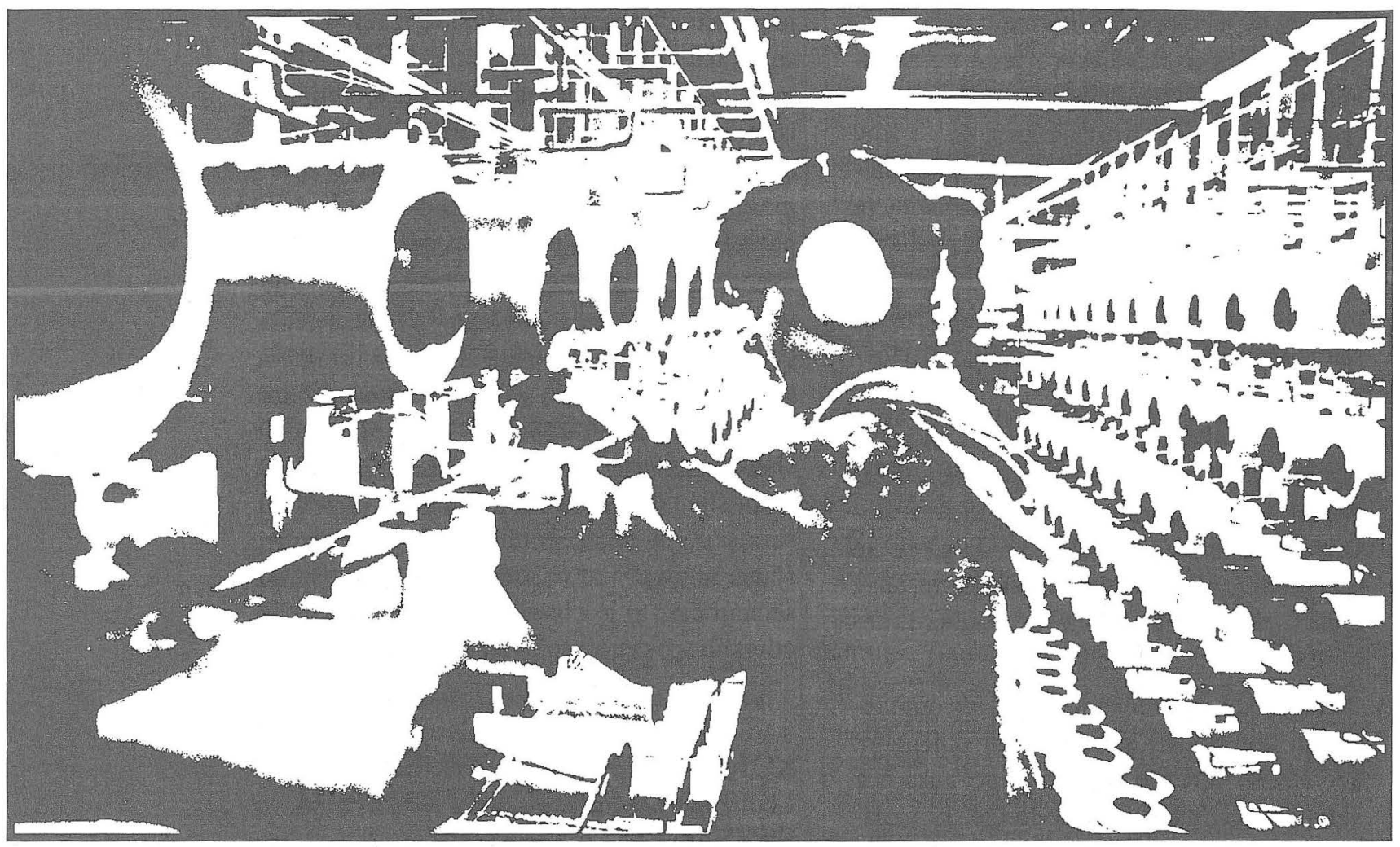

lo idejo o izobraževanju odraslih kot koherentni celoti, po ciljih, obsegu, pomenu, potrebi po sistemski ureditvi itn. povsem primerljivi z izobraževanjem otrok in mladine.

2. Za nastanek zamisli in potrebe po vseživljenjskem učenju je nedvomno zaslužno predvsem ali celo izključno izobraževanje odraslih. Šolanje in izobraževanje otrok in mladine sama po sebi ne potrebujeta nadaljevanja in ju je mogoče izvajati le v začetnem obdobju življenja. Zato se pedagogika v ožjem smislu - kot veda o izobraževanju otrok in mladine - ter oblikovalci in upravljalci sistema izobraževanja otrok in mladine ter šolskega sistema ( $\mathrm{z}$ izjemo redkih vizionarjev, med njimi je bil eden prvih J. A. Komenski) sploh niso ogreli za idejo in za sprejetje načel vseživljenjskosti učenja ter njihovo vpeljevanje v prakso. Še več: strategija vseživljenjskosti učenja ima najpomembnejše nasprotnike $\mathrm{v}$ nosilcih politike in razvoja izobraževanja otrok ter mladine; tudi pojem »začetno izobraževanje jim ni po volji, saj predpostavlja njegovo enako pomembno nadaljevanje $\mathrm{z} \gg n$ ndaljevalnim izobraževanjem « ali izobraževanjem odraslih, to pa je za njih predvsem konkurenčni porabnik že tako omejenih in nezadostnih sredstev.

3. Opirajoč se na koncept vseživljenjskosti učenja in sklicujoč se na današnje ugodne razmere za njegovo udejanjanje (hiter razvoj in zastarevanje znanja; togost šolskega in izobraževalnega sistema ter njegova nezmožnost, da bi sledil hitremu razvoju; razvoj informacijske in učne tehnologije; spremenjeni življenjski slog in uveljavljanje cikličnosti ter prepletanja prej ločenih dejavnosti izobraževanja in dela itn.), je začelo izobraževanje odraslih odločneje kot prej prevzemati pobudo na področju 
vzgoje in izobraževanja. Zahteva, da se tudi izobraževanje odraslih opredeli kot koherenten sistem in da se ga enakopravno obravnava pri sistemskem urejanju in oblikovanju nacionalnih politik vzgoje in izobraževanja. ${ }^{10}$

$\mathrm{S}$ tem splošnim uvodom sem želel vpeljati osrednji del prispevka, to je primerjalni prikaz v zadnjem času nastajajočih nacionalnih projektov ali programov za razvoj izobraževanja odraslih. Še prej pa bi rad opozoril, da gre za dogajanje $\mathrm{v}$ zadnjih, praviloma dveh ali treh, največ petih, letih. Ob koncu 80. let ga namreč sploh še ni bilo. Titmus (1989: 381-387) tedaj ugotavlja, da so se v nekaterih državah šele začeli premikati od »konglomeracije k organski celoti « in vidi možnost, da bi vsaj konceptualno opredelili »ogrodje nacionalnih struktur « in da bi imela pri tem pozitivno vlogo država. Pri tem se opira na načela, namene, vsebine, izvajalske organizacije, odločanje in financiranje pri izobraževanju odraslih ter povezovanje med izobraževanjem odraslih in drugimi področji izobraževanja. Kot najbolj kohezivne sile pri razvijanju »formalnih struktur« ali oblikovanju nacionalnih sistemov s pomočjo države vidi zlasti skupna načela in namene izobraževanja odraslih. Po namenu je mogoče izobraževanje odraslih razdeliti na štiri področja: 1 . izobraževanje kot druga priložnost; 2. izobraževanje za določene vloge ali funkcije v družbi; 3 . izobraževanje za pridobitev znanja in spretnosti, ki jih potrebujemo kot zaposlene osebe za opravljanje dela ali poklica; 4. izobraževanje za osebno bogatitev.

Že če bi upoštevali ta načela in namene, bi bila konceptualizacija in oblikovanje nacionalnih sistemov izobraževanja odraslih prednostna naloga države in njene izobraževalne ter razvojne politike. Prav tako pa najbrž lahko rečemo, da bi jih bilo težko udejanjiti, če jih ne bi podprl nacionalni sistem.
Načela izobraževanja odraslih, kot so: odrasli potrebujejo ustrezne možnosti za izobraževanje; izobraževanje posameznikov (odraslih) je potrebno družbi; možnosti za učenje morajo biti organizirane tako, da zadovoljujejo potrebe posameznika in tudi družbene potrebe; udeležba v izobraževanju odraslih mora biti prostovoljna; izobraževanje odraslih mora biti sestavni del procesa vseživljenjskega izobraževanja; izpeljava izobraževanja odraslih se mora prilagajati temeljnim načelom družbe, v kateri deluje, mora pa tudi sama animirati temeljna načela družbe; čeprav se načela sprejemajo bolj ali manj kot splošnoveljavna (univerzalna) - v praksi se morajo prilagajati možnostim in okoliščinam -, trdno določajo pravice ter možnosti posameznika in tudi interes ter dolžnosti države.

Preden se lotimo primerjalne analize izbranih nacionalnih načrtov in projektov, omenimo še pomembno, zlasti spodbujevalno pa tudi konkretno organizacijsko vlogo, ki sta ju imeli pri tem dve mednarodni organizaciji, ki sta $\mathrm{v}$ svoj program včlenili tudi razvoj in pospeševanje razvoja izobraževanja odraslih, to sta Unesco in OECD. Unesco s svojimi mednarodnimi konferencami o izobraževanju odraslih, ki so postale pravi mejniki v svetovnem gibanju za razvoj izobraževanja odraslih, in v zadnjih letih s sprejemanjem strateških razvojnih načrtov, kot so v letu 1995 sprejeta strategija za srednjeročno obdobje 1996-2001 z geslom »Vseživljenjsko učenje za vse« (Lifelong Learning for All, Unesco, 1995) in dokumenti pete mednarodne konference o izobraževanju odraslih v Hamburgu, 1997 (Unesco, 1997), z geslom »Učenje odraslih: ključ za 21. stoletje« (Adult Learning: A Key for the Twenty-first Century). V obeh se poudarja ključna vloga vlad in državnih politik pri razvijanju izobraževanja odraVseživljenjsko učenje mora postati realnost za vse in prioriteta nacionalnih politik. slih. OECD pa s konkretnimi usmeritvami in akcijami za uveljavitev cilja »vseživljenjsko učenje za vse« (»Lifelong Learning for All«, to geslo je enako, kot je bilo Unescovo) od za- 
četka 90. let. To se je izrazilo na konferenci ministrov za izobraževanje v Parizu leta 1996 (OECD, 1996) s sprejetjem komunikeja ministrov (n. d.: 21-24) in sklepom, da morajo vse države članice zagotoviti, da bo postalo vseživljenjsko učenje realnost za vse ljudi in temeljna prioriteta njihove politike $\mathrm{v}$ naslednjih petih letih.

\section{PRVI CELOVITEJŠI NACIONALNI PROGRAMI IZOBRAŽEVANJA ODRASLIH}

Pri pregledovanju dosegljivih virov smo ugotovili, da bi lahko v našo analizo včlenili le nekaj držav, ki imajo posebej izdelano gradivo za razvoj izobraževanja odraslih, ki ga lahko opredelimo kot razmeroma celovit načrt, strategijo ali razvojni projekt. ${ }^{11}$ Našim merilom so bolj ali manj ustrezali le projekti Velike Britanije, nordijskih držav, Švedske, Finske in Nizozemske. Posebne, vendar za naš namen ne dovolj popolne programe, imata tudi Severna Irska in Danska. V nadaljevanju jih bomo najprej na kratko predstavili in jih nato primerjali $\mathrm{v}$ skladu $\mathrm{z}$ merili primerjalne analize. Predstavitev bo obsegala te vsebinske sklope za prikaz programa: a) identifikacija, b) cilji (skupaj z izhodišči in utemeljitvami), c) izpeljava. ${ }^{12}$

\section{Velika Britanija}

Velika Britanija ima dva programa, ki ustrezata merilom za včenitev $v$ analizo. Upoštevali bomo program, ki je izrecno namenjen razvoju izobraževanja odraslih, to je »The Learning Imperative: National Education and Training Targets and Adult Learners « (Nujnost učenja: nacionalni cilji izobraževanja in usposabljanja ter odrasli učenci). ${ }^{13}$

Program »The Learning Imperative« je sprejelo ministrstvo za izobraževanje in usposabljanje že v letu 1989, po svoji izpeljavi pa je bil razdeljen na tri faze, ki so določale ob- dobja za njegovo udejanjanje: tri leta (1992), šest let (1995) in enajst let (2000); obdobja se $\mathrm{v}$ skupnem programu kumulirajo, program pa še ni končan. Lahko ga označimo kot vseobsegajoč nacionalni program za izobraževanje odraslih, ${ }^{14}$ ki temelji na konceptu vseživljenjskosti učenja in teži $\mathrm{k}$ temu, da bi izenačili pomen izobraževanja odraslih s pomenom in položajem izobraževanja mladine. Program je strokovno pripravil angleški nacionalni inštitut za izobraževanje odraslih (National Institute for Adult and Continuing Education - NIACE).

Nacionalni program izobraževanja odraslih v Veliki Britaniji je po svoji temeljni usmeritvi naravnan na dve področji, to sta: a) temeljno izobraževanje odraslih in b) vseživljenjsko učenje. V skladu s temi področji so opredeljeni tudi njegovi cilji. V svojih temeljnih ciljih izhaja iz podmene, da je izobraževanje odraslih zelo pomemben dejavnik družbenega in tudi posameznikovega razvoja. V nadaljnjih členitvah smotrov, ciljev in utemeljitev $t i$ dve usmeritvi določa posebej za posameznika in posebej za družbo. V utemeljitvah programa se poudarja zlasti to, da je treba s pomočjo izobraževanja (odraslih) povečati gospodarsko tekmovalnost države in $\mathrm{v}$ ta namen uveljaviti koncept vseživljenjskosti izobraževanja, ki še ni dovolj uveljavljen. Za dosego teh ciljev je treba poleg uresničevanja posameznih opisanih ciljev spremeniti ustaljeno prakso.

Program podrobno opredeljuje možnosti in ukrepe za spreminjanje organiziranosti in izpeljave izobraževanja. Pri tem določa temeljne nosilce za izpeljavo programa in načine, kako naj se program izpelje (skupno in po posameznih nosilcih) ter podrobno opredeljuje načine za njegovo izpeljavo. Pomemben dejavnik uveljavljanja strategije nacionalnih ciljev je država s svojimi možnostmi za ko- 
ordiniranje udejanjanja programa in tudi $\mathrm{s}$ svojimi konkretnimi, zlasti zakonskimi, finančnimi in upravnimi možnostmi. Posebej so opredeljene naloge in možnosti lokalne oblasti. Nosilci izpeljave programa za uresničitev kratkoročnih ciljev so sveti za poklicno usposabljanje in zaposlovanje, delodajalci in izvajalci.

\section{Nordijske dežele}

Program z imenom »Nordic Action Programme for the Invigoration of Adult Education in the Future « (Nordijski akcijski program za pospešitev izobraževanja odraslih v prihodnosti) - VOKS FREM (Nordiske, 1992) je bil sprejet leta 1992 za obdobje 1992-1996. Sprejel ga je poseben odbor za razvoj izobraževanja odraslih v nordijskih deželah in je tako primer regijskega razvojnega programa za razvoj izobraževanja odraslih.

Potrebe segajo od zelo širokih, kot je hitro in prožno slediti demokratičnim, socialnim, kulturnim in političnim spremembam, te pa zadevajo tudi izobraženost, znanje in usposobljenost odraslega prebivalstva in delovne sile za hitro reševanje problemov, do ožjih ciljev, naravnanih bodisi k izboljševanju možnosti za izobraževanje za posamezne skupine prebivalstva (ciljne skupine, kot so brezposelni, nezadostno izobraženi, ženske, starejši) bodisi $\mathrm{k}$ razvijanju izobraževanja odraslih na splošno.

Strategija za izpeljavo tega programa temelji na teh konceptualnih prvinah: vseživljenjskost izobraževanja; dostopnost izobraževanja vsem socialnim razredom, še posebej izobrazbeno zapostavljenim (manj izobraženi ali brez izobrazbe, brezposelni); izobraževanje za delo in prosti čas; povezovanje med izobraževanjem mladih in izobraževanjem odraslih; decentralizacija izobraževalne politike prenos odločanja in odgovornosti na lokalne ravni; splošnoizobraževalne ustanove naj postanejo lokalna središča znanja, ki naj skrbijo
Cilji nacionalnega programa nordijskih dežel so naravnani $v$ tri smeri: a) izobraževanje odraslih kot pomembno področje sodelovanja med nordijskimi deželami; b) obvladovanje razmer, ki nastajajo s povezovanjem evropskih držav v Evropsko unjo; c) izobraževanje odraslih.

za razvoj celotne skupnosti, povezovanje z lokalnimi podjetji in izobraževalnimi ustanovami za odrasle; sodelovanje in koordinacija med zdaj preveč ločenima sistemoma splošnega in formalnega izobraževanja ter poklicnega usposabljanja; institucionalna, finančna in tudi ekonomska prednost poklicnemu usposabljanju (med drugim usposabljanju med delom); finančna podlaga in finančne spodbude za izobraževanje odraslih; uporaba novih pedagoških in andragoških metod (učenje na daljavo, multimedijsko učenje, vloga medijev) in načinov motiviranja za učenje; uvajanje izobraževalnih omrežij in programov za različne ravni; internacionalizacija problematike izobraževanja odraslih (vsaj na ravni Evropske unije).

\section{Švedska}

Naslov projekta je »Lifelong Learning on the Job - Steps on the Way towards the Community of Knowledge« (Vseživljenjsko učenje na delu - koraki na poti k skupnosti znanja). Gre za projekt, ki se izpeljuje kot del projekta Leonardo (Danvind, Thysk, 1996). Pri predstavitvi so ga označili kot nacionalno »kampanjo«. Sestavljata ga dva vzporedna razvojna načrta: načrt za predšolsko in šolsko izobraževanje ter načrt za izobraževanje odraslih. Prvini, ki povezujeta oba projekta, sta kakovost in enakopravnost. Program je srednjeročen: začel se je leta 1997, potekal pa bo do leta 2000.

Temeljni cilji programa ne podpirajo vseživljenjskega izobraževanja v najširšem pomenu, temveč se zožujejo na vseživljenjsko učenje kot zviševanje ravni znanja. Tudi pri tem imajo prednost izobrazbeno zapostav- 
Temeljna izhodišča švedskega nacionalnega programa so naravnana na spreminjanje izobraževalnega sistema, da bi ta ustrezneje včlenil izobraževanje odraslih: a) namesto enotnosti dati v izobraževalni politiki večji poudarek enakopravnosti in b) bolj upoštevati znanje ter izkušnje udeležencev izobraževanja.

ljene brezposelne osebe, ki naj bi dosegle stopnjo izobrazbe na ravni triletnega srednjega izobraževanja. Bolj operativno opredeljeni cilji so: zmanjšanje brezposelnosti; izpeljava petletne kampanje pri izobraževanju odraslih; zvišanje izobrazbe oseb, starih od 25 do 55 let, zlasti tistih s pomanjkljivo temeljno izobrazbo, in še posebej brezposelnih iz te ciljne skupine ter tistih zaposlenih, ki jim je treba zboljšati položaj na trgu delovne sile; omogočiti odraslim vpis v izobraževanje s polnim študijskim časom. Pomembno vlogo pri izpeljavi in udejanjanju programa ima država, ki zagotavlja pomembne strateške prvine načrta, na podlagi katerih naj bi se oblikovala ustrezna politika izobraževanja. Načrt podrobno navaja vlogo države. Poleg že navedenega partnerstva med državo in drugimi nosilci ter subjekti izobraževanja program jasno razmejuje odgovornosti države in mestne uprave. Strategija natančno opredeljuje merila za opredelitev vloge države in lokalne (mestne) uprave pri subvencioniranju izobraževanja. Pomemben dejavnik v strateški izpeljavi programa je zakonodaja, ki podpira zlasti učenje ob delu. Udeležbo je treba spodbujati s sistemom financiranja različnih oblik izobraževanja (javna denarna podpora, posebni izobraževalni računi, davčne olajšave, vlaganje dobička podjetja v razvoj usposobljenosti osebja), ki se uveljavljajo bodisi z zakonodajo bodisi $\mathrm{z}$ neobveznim dogovarjanjem. V opisanem programu za zvišanje ravni znanja in vseživljenjsko učenje se nacionalna obveznost omejuje na zvišanje ravizobrazbe. Izobraževanje odraslih se opre-

deljuje kot odgovornost posameznika, države, podjetja in sindikatov.

\section{Nizozemska}

Program »Lifelong Learning« (Vseživljenjsko učenje) je bil sprejet kot nizozemski nacionalni akcijski program leta 1997 po enoletni razpravi. Pobudo zanj je dal minister za izobraževanje, kulturo in znanost. Pripravljal ga je ministrski komite, ki so ga sestavljali ministri (za ekonomske odnose, socialne zadeve, kmetijstvo in ribištvo, izobraževanje, kulturo in znanost), državni sekretar za izobraževanje in strokovnjaki, vodil pa ga je predsednik vlade.

Za vsako od navedenih prednostnih skupin je posebej opredeljeno, kako odpravljati ovire za vseživljenjsko učenje. Program obsega vrsto konkretnih ukrepov, ki jih lahko povežemo v te sklope: a) razvijanje in spodbujanje razvoja zavesti o pomenu izobraževanja; b) financiranje; c) čas: racionalizacija z izobraževanjem na delovnem mestu (povezava med učenjem in delom); č) razvijanje potreb po izobraževanju in njihovem zadovoljevanju; d) posebne spodbude za marginalizirane skupine zaposlenih (starejši, z nizko formalno izobrazbo, pogodbeni delavci); e) posebne spodbude za brezposelne; f) reforma izobraževa-

Nizozemski nacionalni program je zgrajen na podmeni, da temelji koncept vseživljenjskosti učenja na samozavestnih $>$ porabnikih izobraževalnih storitev. Zato je njegov temeljni smoter oblikovanje takšne nacionalne (vladne) politike, ki bo odstranjevala ovire pri vpeljevanju in udejanjanju vseživljenjskega izobraževanja, to pa bo dosegla predvsem s splošnimi ukrepi za spodbujanje izobraževanja pripadnikov ciljnih skupin (starejši zaposleni, zaposleni brez temeljnih kvalifikacij, pogodbeni delavci, iskalci zaposlitve). 
nja; g) spremenjena vloga učitelja; h) preprečevanje marginalnosti se začne že pri otrocih iz marginaliziranih družin in okolij, zlasti pri etničnih manjšinah. Projekt se izpeljuje s partnerskim sodelovanjem, za njegovo izpeljavo skrbi vlada in ga tudi vodi. Uresničevanje programa podpira tudi zakonodaja.

Nacionalni programi razvoja ali strategije izobraževanja odraslih so dokumenti, ki bi morali temeljiti na sprejeti ali vsaj zasnovani in izdelani koncepciji izobraževanja odraslih. Temelji, to je opredelitev značilnosti in možnosti izobraževanja odraslih, morajo izhajati iz znanstvenih spoznanj andragogike in drugih ved, ki določajo izobraževanje odraslih kot področje dejavnosti. Seveda pa je treba tako oblikovani program združiti $\mathrm{z}$ aktualnimi družbenimi okoliščinami in možnostmi.

Poleg izbranih štirih programov bi lahko v širšem izboru za našo analizo upoštevali še druge programe, ki pa povsem ne ustrezajo merilom, po katerih smo izbirali primere za analizo. ${ }^{15}$

\section{STROKOVNO-KONCEPTUALNE IN RAZVOJNO-POLITIČNE PRVINE NACIONALNIH STRATEGIJ}

Primere nacionalnih razvojnih programov izobraževanja odraslih, ki smo jih predstavili v tem prispevku, bomo v nadaljevanju ocenili tako, da bomo skušali ugotovili, na kakšnih strokovno-konceptualnih in tudi razvojno-političnih prvinah temeljijo. Na splošno nas bo zanimalo, kako se $\mathrm{v}$ njih srečujeta stroka in politika, podrobno pa, katere prvine vsebujejo. Da bi to lahko naredili, bomo skušali oblikovati hipotetični model prvin, ki naj bi jih vseboval nacionalni razvojni program ali strategija. Ta model bomo izdelali sami, upoštevajoč spoznanja, ki smo jih dobili iz temeljitega primerjalnega študija.

\section{Sestavine hipotetičnega modela nacionalnega razvojnega programa za izobraževanje odraslîh}

a) Splošne in širše družbene, zgodovinske, politične in pravne določnice

Najpomembnejša družbena, politična in zgodovinska izhodišča ter znanstvena spoznanja, na katerih temelji potreba po koncepciji in strategiji izobraževanja odraslih: splošni zgodovinski in kulturni razvoj, družbeni sistem in politične spremembe, razvoj in zmogljivosti gospodarstva, praṿnonormativne podlage, splošne značilnosti razvoja izobraževanja.

\section{b) Temeljni cilji programa}

Družbeni, politični ter strokovni cilji in smotri.

\section{c) Teoretično-pojmovne opredelitve izobraževanja odraslih}

Znanstveno zasnovane opredelitve in sheme sistema ter delovanja izobraževanja odraslih; zgodovinski razvoj in tradicija, sodobno pojmovanje in pojavnost izobraževanja odraslih $\mathrm{v}$ svetu in opredelitev pomena najpomembnejših pojmov in dejavnikov ter razmejitve med njimi, če je potrebno.

\section{č) Potrebe po izobraževanju odraslih}

$\checkmark$ nacionalnih strategijah izobraževanja odraslih se srečujeta moč politike in moč stroke.
Potrebe v skladu z najbolj grobo klasifikacijo področij in vrst izobraževanja odraslih: splošna populacija - zaposleni; splošno poklicno; temeljno - nadaljnje; začetno - nadaljevalno. Predstavitev potreb v perspektivi časa: sedanjost - preteklost - prihodnost; metodologija ugotavljanja, spremljanja in načrtovanja potreb. 


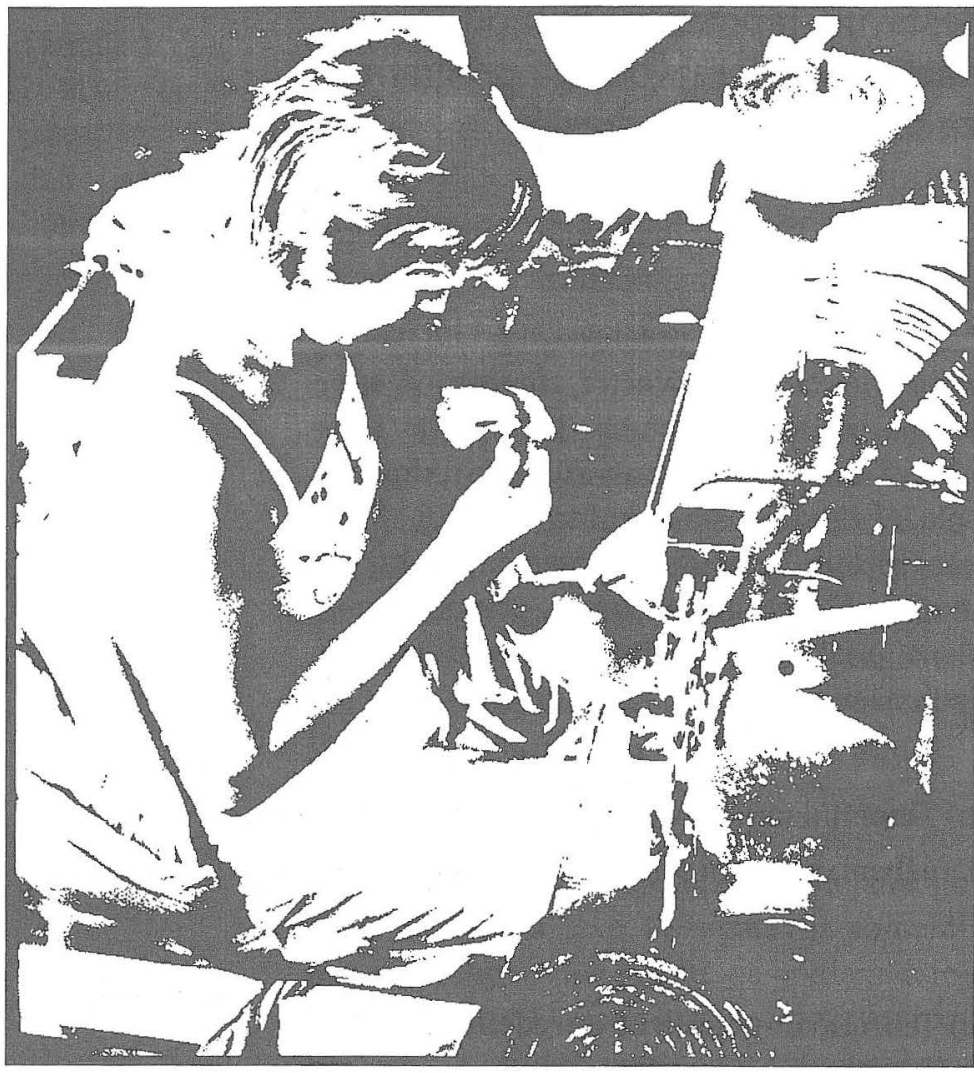

d) Sistem in organizacija ter omrežje izobraževanja odraslih $\mathbf{v}$ državi

Shema delujočih področij ter osnovnih vrst izvajalskih organizacij in ponudbe programov.

\section{e) Zdajšnja sistemska ureditev izobraževanja odraslih}

Temeljne prvine sistemske ureditve so upravljanje, zakonodaja, mreža organizacij, financiranje, razvoj infrastrukture in razvoj osebja.

\section{f) Obstoj nacionalnega programa}

Temeljna izhodišča, temeljne prvine, prioritetna področja in programi, kakovostna merila, povezave, usklajevanje in financiranje.

\section{g) Strategija vseživljenjskosti učenja}

Nacionalni razvojni program izobraževanja odraslih kot del strategije vseživljenjskosti učenja v državi.

\section{PRIMERJAVA IZBRANIH \\ NACIONALNIH RAZVOJNIH PROGRAMOV ZA IZOBRAŽEVANJE ODRASLIH PO HIPOTETIČNEM MODELU}

Oglejmo si zdaj še enkrat predstavljene primere nacionalnih razvojnih programov izobraževanja odraslih iz Velike Britanije, Švedske, Nizozemske in nordijskih držav in jih ocenimo po tem, koliko zadovoljujejo prvine našega hipotetičnega modela.

\section{Splošne in širše družbene, zgodovinske, politične in pravne določnice}

Pri tem je najtemeljitejši program nordijskih držav, ki ga lahko označimo kot temeljitejšo analizo okoliščin, značilnih za regijo - nordijske države. Analiza ne ostaja le v regionalnih okvirih, temveč obravnava regijo tudi iz širšega zornega kota in okoliščin - Evropske unije. Okoliščine prikazuje tudi v zgodovinskem okviru in časovni razsežnosti (sedanjost in prihodnost). Išče prvine regionalne (nordijske identitete). Opozarja tudi na gospodarske usmeritve (ne podrobno) in na pretok delovne sile. Delno izpolnjuje zahteve te prvine tudi program Velike Britanije, ki izhaja predvsem iz ocen njenega položaja $\mathrm{v}$ svetu, pri tem pa zlasti ocenjuje uspešnost (svetovno konkurenčnost) njenega gospodarstva in ustreznost njene delovne sile za takšne potrebe. Drugih širših (zgodovinskih kulturnih, socialnih, političnih itn.) razsežnosti program ne razčlenjuje. Ni analize delovanja izobraževalnega sistema v celoti, so pa poudarjeni nekateri njegovi pomanjkljivi učinki (na primer slaba izobrazbena sestava zaposlenih). Programa Švedske in Nizozemske ne obravnavata širših okoliščin ali pa se nanje le sklicujeta. Pri programu Švedske je v ospredju družbeni problem brezposelnost in njegovo reševanje. 


\section{Temeljni cilji programa}

Program nordijskih držav zastavlja cilje široko, pri tem pa ostaja na globalni ravni. Vendar upošteva vse pomembne razsežnosti, ki jih je mogoče zajeti s takšne perspektive, to so zlasti: obseg in kakovost izobraževanja, področja izobraževanja (splošno neformalno in formalno/poklicno) ter vsebine, metode in organiziranost izobraževanja. Tudi cilji programa Velike Britanije so zelo sistematično in natančno opredeljeni. Prevladujejo širši družbeni cilji, tesno povezani z opredelitvami možnosti izobraževanja. Program Nizozemske poleg ožje opredeljenih ciljev programa vključuje tudi reformo celotnega izobraževalnega sistema, za odrasle in tudi za mladino. Vendar ga ne obravnava $v$ vsej njegovi celovitosti, temveč le iz zornega kota spodbujanja učenja ter možnosti in motivacije za učenje ali kot možnost za odpravljanje ovir za učenje za celotno populacijo, hkrati s tem pa tudi za obravnavane ciljne skupine. Cilji programa Švedske so strogo namensko in ožje naravnani na ciljno skupino zaposlenih/brezposelnih z nizko temeljno izobrazbo; na spodbuditev vpisa $\mathrm{v}$ formalno izobraževanje (pridobitev stopnje izobrazbe); na urejanje razmer na trgu delovne sile.

\section{Teoretično-pojmovne opredelitve izobraževanja odraslih}

Program nordijskih držav se ukvarja s konceptom in filozofijo izobraževanja odraslih le na splošno, kolikor je potrebno za pojasnjevanje posameznih delov programa. Te prvine ne vidi kot temeljnega pogoja za oblikovanje drugih prvin programa. Opozarja pa na potrebo po takšnih opredelitvah, zlasti zaradi socialnih, tehnoloških, motivacijskih in drugih sprememb, ki jih ugotavljamo. Programa Velike Britanije in Švedske praviloma te prvine ne vključujeta ali le toliko, kolikor je potrebno za pojasnjevanje vseživljenjskosti učenja in njegove povezanosti $\mathrm{z}$ izobraževanjem odraslih. Program Švedske daje nekaj več poudarka pojasnjevanju pomena učenja ob delu za različne partnerje $v$ izobraževanju in dejavnikom, ki vplivajo na motivacijo za učenje. Pojasnjuje širši in ožji pogled na vseživljenjsko učenje. Program Nizozemske te prvine sploh nima.

\section{Potrebe po izobraževanju odraslih}

$\mathrm{V}$ mejah z dokumentom omejenega prostora daje program nordijskih držav celovito analizo potreb, ki se ne omejujejo na potrebe posamezne ciljne skupine ali posameznega cilja, temveč zadevajo vse izobraževanje odraslih, za delo in tudi za prosti čas. Potrebe - zdajšnje in prihodnje - prikazuje tudi v časovni razsežnosti. Če nima na voljo podatkov za prihodnost, opozarja na potrebo, da bi se te potrebe temeljiteje raziskale. Drugi programi ne vsebujejo celovite analize potreb. Program Velike Britanije opredeljuje le predlog za načrtno preučevanje potreb na V skoraj vseh
nacionalnih pro-
gramih je izobra-
ževanje odraslih
pomanjkljivo
opredeljeno. različnih ravneh kot ena njegovih strateških prvin, program Nizozemske pa analizira potrebe le iz zornega kota obravnavanih ciljnih skupin in še pri tem namenja večjo pozornost spodbujanju potreb kot pa njihovemu ugotavljanju in analiziranju. V programu Švedske ni celovite analize potreb, so le podatki, ki so v skladu z ožje zastavljenimi cilji programa.

\section{Sistem in organizacija ter omrežje izobraževanja odraslih v državi}

Strukturi, delovanju (organiziranost, inovacije) in razmerjem med posameznimi deli sistema izobraževanja odraslih (mladi - odrasli; splošno neformalno - formalno - poklicno; šolsko - ob delu) namenja program nordijskih 
držav zadostno pozornost, pa tudi drugim dejavnikom pri izobraževanju odraslih (na primer motivaciji). Očitno je, da je program še posebej naravnan na izboljšanje delovanja sistema izobraževanja odraslih. Program Nizozemske le bolj opozarja na potrebo po reformi celotnega izobraževalnega sistema, ki je ovira za udejanjanje novih potreb možnosti pri izobraževanju odraslih in tudi za mladino. Izhodišče so koncept vseživljenjskosti učenja in spremenjene zahteve, ki iz njega izhajajo za celotno izobraževanje. Vendar ga program ne obravnava $v$ vsej njegovi celovitosti, temveč le iz zornega kota spodbujanja učenja ter možnosti in motivacije za učenje ali kot možnost odpravljanja ovir za učenje za celotno

\section{Za izboljšanje delovanje sistema izobraževanja odraslih si najbolj prizadevajo $v$ nordijskih deželah.}

populacijo, hkrati s tem pa tudi za obravnavane ciljne skupine. Program Velike Britanije temelji na analizi nekaterih pomanjkljivosti izobraževanja odraslih in njegovega zdajšnjega delovanja, na primer naravnanosti programov, strukture in funkcij organizacij, posameznih pomanjkljivosti $v$ delovanju in sistemu. Pri programu Švedske ni celovitega prikaza sistema izobraževanja odraslih, temveč se prikaz omejuje na ožje zastavljene cilje programa. Vendar ga lahko označimo za specifičnega, saj ima vrsto drugih prikazov sistema in njegovega delovanja, na katere se tudi sklicuje.

\section{Zdajšnja sistemska ureditev izobraževanja odraslih}

Čeprav ne zelo podrobno, obravnava program nordijskih držav večino področij za sistemsko urejanje izobraževanja odraslih: upravljanje, financiranje, mrežo in zmogljivosti (različne izvajalce), programe, razvoj kadrov. Manj se ukvarja z zakonodajo in infrastrukturo. Pobude za ustreznejšo sistemsko ureditev so pomembna sestavina programa Velike Britanije in bi jo, poleg natančno opredeljenih ciljev, označili kot pomembnejši del celotnega programa. A tudi $v$ tem delu je program selektiven, poudarja le nekatere sistemske ukrepe, ne obravnava pa sistema v celoti. V programu Švedske je to najtemeljiteje zastopana prvina našega hipotetičnega modela v programu. Pozornost se namenja vprašanjem omrežja in delovanja izvajalcev ter tudi upravljanja, največjo težo pa daje sistemom financiranja in zakonodaji. Povezovalna prvina vseh navedenih sistemskih področij je partnerstvo. Manj pozornosti se posveča infrastrukturi in razvoju kadrov. Program Nizozemske opredeljuje sistemsko ureditev le iz zornega kota obravnavane cilje skupine. Sistemski ukrepi so naravnani na odpravljanje sistemskih ovir za uspešnejše izobraževanje marginaliziranih delov prebivalstva. Na tem ožjem segmentu pa so dovolj razčlenjeni in obsegajo sistemsko urejanje vprašanj upravljanja, financiranja, razvoja omrežja in tudi usposabljanja kadrov. Predlagajo tudi možnosti za izboljšanje infrastrukture.

\section{Obstoj nacionalnega programa}

Program Velike Britanije ne imenuje posebej kakega celovitega nacionalnega programa, temveč ponuja oblikovanje strategij in tudi opredeljuje njene prvine, tako da lahko rečemo, da je nekakšen nacionalni program sestavina tega nacionalnega razvojnega programa, ki ga obravnavamo. Tudi neke vrste spremljevalni del programa - priporočila NIACE kot strokovnega nosilca programa - lahko ocenimo kot nekakšen nacionalni program. Program Švedske je v samem besedilu označen kot »strategija«, operativno pa kot »kampanja«; slednje najustrezneje označuje njegovo pravo naravo. Tudi program Nizozemske je realno označen kot »nacionalni akcijski program «. Program nordijskih držav te prvine ne vključuje, ker ni narejen le za eno državo, temveč za območje, celoten program pa se imenuje »akcijski program «. 


\section{Strategija vseživljenjskosti učenja}

Program Velike Britanije nedvomno temelji na načelih in strategiji vseživljenjskosti učenja. Celovita strategija v programu ni zajeta, vendar so kasneje izdelali poseben dokument, ki podrobno opredeljuje strategijo vseživljenjskosti učenja (The Learning Age). Tudi vsi drugi obravnavani programi temeljijo na načelih vseživljenjskosti učenja, vendar ta strategija ni celoviteje prikazana, temveč je pretežno le aplicirana na problematiko obravnavanih ciljev ali pa so v njih le nekatera temeljna izhodišča kocepcije vseživljenjskosti učenja.

\section{SKLEPNE MISLI}

Analizirali smo štiri primere nacionalnih razvojnih programov za izobraževanje odraslih, programe Velike Britanije, Švedske, Nizozemske in nordijskih držav. Na podlagi analize obravnavanih programov po posameznih prvinah lahko povzamemo:

1. Obravnavani programi ne izpolnjujejo vseh zahtev našega hipotetičnega modela za pripravo nacionalnega razvojnega programa in strategije za razvoj izobraževanja odraslih. Izjema je le Akcijski program za razvoj izobraževanja odraslih v nordijskih državah, a tudi ta razmeroma zadovoljuje zahteve le pri šestih prvinah, pri dveh pa je nepopoln. Zato jih ne moremo šteti za primere celovite koncepcije in strategije za izobraževanje odraslih. Tega jim seveda ne očitamo, saj se tudi sami ne razglašajo za celovite programe, temveč bolj za »akcijski program, kampanjo, strategijo« itn., želimo le opozoriti, da države tako celovitih razvojnih programov (še) nimajo, a da bi bilo to za celovit razvoj izobraževanja odraslih, posebej še v koncepciji in strategiji vseživljenjskosti učenja, potrebno. To deloma dokazuje edina izjema - program za pospešitev razvoja izobraževanja odraslih $\mathrm{v}$ nordijskih državah, za katerega lahko domnevamo, da je zastavljen tako zato, ker ni nastal pod pritiskom ožjih ciljev razvojne politike posamezne države, kjer prevladuje potreba po zadovoljitvi aktualnih ali akutnih družbenih (gospodarskih, socialnih, političnih ciljev, ciljev HRD ipd.).

2. V programih najbolj pogrešamo predvsem dve prvini, to sta: širša analiza družbenih razmer, v katerih naj bi potekale ali že potekajo načrtovane razvojne spremembe pri izobraževanju odraslih, in celovito ter temeljito strokovno (na znanstvenih ugotovitvah temelječo) koncepcijo za razvoj izobraževanja odraslih ter opredelitve pojavnosti, vloge in pomena njenih prvin (vštevši pojasnjevanje in razmejevanje pojmov in njihovega pomena). Zato, denimo, ne more priti $v$ razvojnih programih do jasne postavitve zahteve po tem, da se izobraževanje odraslih sistemsko opredeli kot enakopravno področje vsega izobraževanja, ki je enakovredno (ne pa enako) izobraževanju otrok in mladine. Iz navedene pomanjkljivosti izhaja tudi nepopolnost programov $\mathrm{v}$ drugih prvinah, kot so cilji, opredelitev potreb, delovanje sistema in sistemsko urejanje. Zato pri večini programov naravnavajo vsebino teh prvin na ožje cilje, izbrane ciljne skupine, aktualne družbene zahteve itn. S tem le odpravljajo aktualne ovire, ne zagotavljajo pa stabilnega razvoja v celoti.

3. Če bi bili programi celoviti, bi lahko aktualne družbene potrebe, nekaj smo jih kot primer že navedli, reševali s sprejemanjem posebnih (delnih, funkcionalnih, usmerjenih, področnih, panožnih itn.) nacionalnih programov, ki bi jim ustrezala imena, kot so »akcijski, sanacijski 
program, kampanja« ipd. Tako pa so ti edini nacionalni programi, ki smo jih lahko našli ( $\mathrm{z}$ že navedeno izjemo - nordijske države), prav to - akcije, kampanje, sanacije. $\mathrm{Z}$ navedeno ugotovitvijo seveda ne želimo zmanjševati pozitivnega dejstva, da te programe sploh imamo (še do nedavnega nismo imeli niti takšnih), in seveda ne njihove kakovosti. Gre za kakovostno pripravljene programe, ki pa seveda ne morejo nadomestiti celovitih nacionalnih razvojnih programov za izobraževanje odraslih.

4. Pomembna skupna značilnost in odlika vseh obravnavanih programov je ta, da vsi bolj ali manj temeljijo na koncepciji in strategiji vseživljenjskosti učenja. Vseživljenjskost učenja opredeljujejo kot najširši okvir in filozofijo za svoje cilje ter vsebinsko sestavo. To je nedvomno izjemno pomembno in obeta, da bi se lahko takšni ali podobni nacionalni programi v prihodnosti pomembno izpopolnili. To bo narekovala že sama po sebi koncepcija vseživljenjskosti učenja, ki se bo postopoma razširila na vse izobraževanje in bo tako tudi $s$ perspektive začetnega izobraževanja »pritiskala« na ustrezno koncipiranje in izpeljevanje nadaljevalnega izobraževanja (izobraževanja odraslih). V obravnavanih programih gre seveda le za uporabo koncepcije vseživljenjskosti učenja, ne pa za njeno podrobnejšo razčlenitev in strategijo. Primer Velike Britanije kaže, da so tam to potrebo že začutili, saj so pripravili še poseben nacionalni program $\mathrm{z}$ naslovom Obdobje učenja (The Learning Age).

Naša analiza je nastala kot del projekta Koncepcija in strategija izobraževanja odraslih v Sloveniji. Povedali smo že, da njena priprava poteka že nekaj let in je zdaj v zadnji fazi pred objavo. Strategija razvoja izobraževanja odraslih temelji na našem hipotetičnem modelu. Upoštevane so vse prvine modela in tudi to, kar smo navedli v sklepnih ugotovitvah. Tudi z njo želimo potrditi izvedljivost takšnega projekta, kot je priprava celovitega nacionalnega programa za razvoj izobraževanja odraslih. Pri nas sočasno poteka tudi priprava posebnega nacionalnega programa izobraževanja odraslih in strategije vseživljenjskosti učenja.

\section{LITERATURA}

Danish Research and Development Centre (1988): New Approaches to Adult Education in Denmark. Danish Research and Development, Centre for Adult Education. Kopenhagen (23 strani).

Danvind, Eva-Maria, Elvy Thysk (1998): Over 45. A Leonardo Project. Extract from a Report 1998. First National Report from Sweden.

Department of Education and Science (1998): Adult Education in an Era of Lifelong Learning. Stationary Office, Dublin.

Drofenik, Olga idr. (1998): Nacionalni program izobraževanja odraslih. Strokovne podlage. Andragoški center Slovenije, Ljubljana (1. zvezek - Razvojne usmeritve).

Jelenc, Zoran, Ana Krajnc, Metka Svetina (1993): Znani andragogi o andragogiki. Sintezna predstavitev stališč iz raziskave in podlage za oblikovanje skupnih stališč. V: Premislek o izobraževanju odraslih in razvoju (ur. Zoran Jelenc in Metka Svetina). Andragoški center Slovenije, Ljubljana, 293-327.

Jelenc, Zoran, Metka Svetina ((ur.): Premislek o izobraževanju odraslih in razvoju (1993). Andragoški center Slovenije, Ljubljana.

Jelenc, Zoran (ur.) (1994a): Izobraževanje odraslih kot dejavnik razvoja Slovenije. Raziskovalno poročilo (6 zvezkov, skupno 1779 strani). Andragoški center Republike Slovenije, Ljubljana.

Jelenc, Zoran (1994b): Potreba po koncipiranju in sistemski ureditvi izobraževanja odraslh in razvijanje izhodišč za novo koncepcijo izobraževanja odraslih v Sloveniji. V: Snovanje in sistemsko urejanje izobraževanja odraslih - Splošna izhodišča in primerjalni pregled stanja v Sloveniji (vodja podprojekta Z. Jelenc). RP Izobraževanje odraslih kot dejavnik razvoja Slovenije. Andragoški center Slovenije, Ljubljana, 7-10 in 11-31 (Raziskovalno poročilo, 1).

Jelenc, Zoran (1994c). Rethinking adult education for development. Introductory Presentation. V: Rethinking Adult Education for Development II. (Ed. M. Svetina). Slovene Adult Education Centre, Ljubljana, 27-40 (zbornik). 
Jelenc, Zoran (1995). The state role and competence in the adult education development promotion and its system regulations. International seminar Legislative and Policy Issues in the Field of Adult Education. Council of Europe, Strasbourg, 25.-27. 10. 1995 (tipkopis, 3 strani).

Merriam, Sharan B., Phyllis M. Cunningham (ur.) (1991): Handbook of Adult and Continuing Education. Jossey-Bass Publishers, San Francisco, Oxford.

Ministry of Education (1998): Lifelong Learning. The National Action Programme of the Netherlands. Ministry of Education Culture and Science, Den Haag.

NIACE (1993): The Learning Imperative. National Education and Training Targets and Adult Learneres. A NIACE Policy Discussion Paper. NIACE, marec 1993 (tipkopis, 54 strani).

NIACE (1998): The Learning Age: a renaissance for a new Britain. NIACE, Leicester (The Green Paper).

NIER (1997): Comparative Studies on Lifelong Learning Policies. Report of a NIER/UIE joint research project. Tokio.

Nordiske (1992): Nordic (Action Programme for the Invigoration of Adult Education in in the Future. VOKS FREM (1992-1996). Nordiske Seminar-og Arbejdsrapporter 1992: 564. Kopenhagen (18 strani).

OECD (1996): Lifelong Learning for All. Meeting of the Education Committee at Ministerial Level, 16.-17. januar 1996. OECD, Pariz.

Okamoto, Kaoru (1994): Lifelong Learning in Japan. Strategy, Practices and Challenges. Ministry of Eduction, Science and Culture, Tokio.

Rubenson, Kjell (1997): »Adult Education and Training: The Poor Cousin. An Analysis of Reviews of National Policies for Education. University of British Columbia \& Linkoping University, marec 1997 (Paper prepared for the Educational Committee of OECD, tipkopis, 28 strani).

Titmus, Colin: (1979): Some Considerations on Relationship between the Parts of Adult Education, at the Level of Macro and Micro Models. ECLE Expert Meeting on out-of-school Adult Education, Kladno (konferenčno gradivo, tipkopis).

Titmus, Colin J. (ur.) (1989): Lifelong Learning of Adults: An International Perspective. Pergamon Press, Oxford, New York idr.

Titmus, Colin J. (1989): The Field of Adult Education. V: Lifelong Education for Adults: An International Perspective (1989). (Ed. by C. J. Titmus). Pergamon Press, Oxford, New York idr., 13.

Titmus, Colin J. (1989): National Programs and OrganiLatlun. V: Lifelong Education for Adults: An International Perspective (1989). (Ed. by C. J. Titmus). Pergamon Press, Oxford, New York idr., 13.

Titmus, Colin J. (1996): Adult Education: Concepts and
Principles. V: International Edcyclopedia of Adult Education and Training. (Ed. by: Albert C. Tuijnman). Pergamon, Oxford, New York idr., 9-18.

Tuijnman, Albert (ur.) (1996): International Encyclopedia of Adult Education and Training. C.. Pergamon, Oxford, New York idr.

Unesco (1995): Medium-term Strategy 1996-2001. Unesco, Pariz.

Unesco (1997): Progress, achievements and problems: a retrospective review of adult education since 1985. (Working document). UNESCO, Fifth International Conference on Adult Education, Hamburg 1997.

${ }_{1}$ Prispevek je bil predstavljen na mednarodni konferenci za primerjalno andragogiko, ki je bila v Radovljici od 10. do 12. septembra 1998. Organizirala sta jo Mednarodno združenje za primerjalno andragogiko (International Society for Comparative Adult Education - ISCAE) in Andragoški center Slovenije. Nekoliko skrajšani prispevek je bil objavljen $v$ angleščini v posebnem zborniku ISCAE.

${ }^{2}$ Avtor tega besedila se s temi vprašanji, zlasti s sistemsko ureditvijo izobraževanja odraslih v Sloveniji, kontinuirano ukvarja že dobrih petnajst let, zgoščeni izidi tega dela bodo še letos strnjeno predstavljeni $v$ besedilu z naslovom Strateška in konceptualna opredelitev sistema in razvoja izobraževanja odraslih $v$ Sloveniji, ki bo objavljeno v posebni publikaciji. To tematiko pa poglablja z raziskovanjem teoretičnih podlag konceptualizacije in sistemskega urejanja izobraževanja odraslih, torej andragogike in sistemskih podlag za razvoj prakse, $v$ projektu z naslovom Celovita shema znanosti in sistema izobraževanja odraslih, ki jo kot temeljno raziskavo financira Ministrstvo za znanost in tehnologijo Republike Slovenije.

${ }^{3}$ Bolj ali manj imajo vse države, razvite in manj razvite, s kateregakoli geografskega, kulturnega, političnega ali družbenega območja, oblikovane sisteme vzgoje in izobraževanja otrok ter mladine, še posebej njihovega šolanja. Čeprav se njihove ureditve šolstva in izobraževanja med seboj razlikujejo, so vendarle bolj ali manj oblikovane po podobnih skupnih splošno-teoretičnih (filozofskih), posebnih (pedagoških, didaktičnih, metodičnih, organizacijskih itn.) ali družbeno-sistemskih shemah. Po njih se oblikujejo strokovne in sistemske rešitve (organiziranost, programi in vsebine, oblike, metode in modeli, upravljanje, zakonodaja in financiranje, razvojna infrastruktura, razvoj kadrov itn.), razvojne paradigme ter doktrine, strokovno izrazje in druga sistemska ter konceptualna vprašanja.

${ }^{4}$ Gre za znano opredelitev, ki jo je sprejela generalna skupščina Unesca na svojem zasedanju v Nairobiju leta 1976. Sicer pa je za andragoge značilno to, da na srečanjih (zlasti mednarodnih), ko razpravljajo o vprašanjih izobraževanja odraslih, prvi dan predvsem razčiščujejo 
vprašanje, o čem govorimo, ko uporabimo pojem izobraževanje odraslih.

5 Študijo so zahtevali ministri držav članic $O E C D$, da bi z. njo identificirali prioritetna področja nacionalnih izobraževalnih politik $v$ teh državah in ugotovili značilnosti delovanja njihovih izobraževalnih sistemov. S študijo je bilo zajeto obdobje ob koncu 80. in v začetku 90. let, avtor študije pa je pri svoji analizi uporabil nacionalna poročila, ki so bila izdelana v obdobju 1990-1996. Upoštevana so bila poročila Avstrije, Belgije, Češkoslovaške in Češke, Danske, Finske, Francije, Grčije, Irske, Madžarske, Mehike, Nizozemske, Norveške, Poljske, Švedske in Švice, skupno torej 15 držav.

${ }^{6}$ Da bi se zanesljivo vedelo, da govori o celoti izobraževanja odraslih, avtor praviloma uporablja sintagmo »izobraževanje in usposabljanje odraslih«, kar seveda pomeni, da vanjo včlenjuje vse vrste in področja izobraževanja odraslih.

7 V poročilu je sicer še vrsta podrobnejših in konkretnih kritičnih ugotovitev, ki pa so večinoma zajete v navedenih treh splošnih kategorijah in jih $v$ našem prispevku na tem mestu ne bomo posebej navajali.

${ }^{8}$ Gre za raziskavo Znani andragogi o andragogiki, v kateri smo slovenski avtorji Zoran Jelenc, Ana Krajnc in Metka Svetina s posebrim vprašalnikom spraševali znane andragoge $z$ vsega sveta, kaj mislijo o andragogiki in izobraževanju odraslih; med drugim smo jih vprašali tudi, ali mislijo, da je izobraževanje odraslih celovit sistem ali ne. Dobili smo odgovore 84 strokovnjakov iz $31 \mathrm{dr}$ žav, kar je razmeroma dovolj reprezentativen vzorec strokovnjakov za andragogiko z različnih delov sveta.

${ }^{9}$ Avtor zanimive opredelitve, $k i$ je navedena na koncu, je botsvanski andragog angleškega rodu Frank Youngmann. (Jelenc, Krajnc, Svetina 1993: 287).

10 Čeprav marsikdo ne pripisuje velikega pomena temu, da se marsikje označuje izobraževanje otrok in mladine z izrazom »redno«, izobraževanje odraslih pa kot »izredno", se mi zdi sprememba tovrstne terminologije simbolično in praktično pomembna in ji pripisujem vrednostno konotacijo. V sistemu vseživljenjskosti učenja, če ga hočemo dosledno uresničiti, takšno razlikovanje ni konsistentno in sprejemljivo.

II Pri tem je treba upoštevati tudi jezik kot omejevalni dejavnik za uporabo gradiva za naše namene. Gradivo, ki ni napisano v enem od širše uporabnih svetovnih jezikov, nam seveda ni bilo dostopno.

12 Na tem mestu si seveda ne moremo privoščiti podrobnejšega prikaza, zato se bo naš opis omejil na prikaz, bistvenih prvin programa, pri čemer se lahko zgodi, da bomo kako prvino namerno ali morda tudi nehote poenostavili.

13 Drugi je program The Learning Age (Era učenja), ki ga na kratko opisujemo na drugem mestu.

${ }^{14}$ Ta vseobsegajočnost in celovitost se kaže v sintagmi »izobraževanje in usposabljanje", v enakem pomenu kot smo ga že označili pri prikazu analize K. Rubensona. Namesto navedene sintagme bomo uporabljali pojem »izobraževanje odraslih«, da ne bi brez potrebe vnašali zmede, ko bomo primerjali različne nacionalne programe med seboj; pojem izobraževanje odraslih v naši rabi nima takšnega pomena, kakršnega ima v tradicionalni angleški rabi, ko označuje le splošno neformalno izobraževanje.

$15 \mathrm{~V}$ širšem izboru lahko omenimo te programe: že omenjeni program Velike Britanije Green Paper »The Learning Age«, ki bi ga lahko označili kot vizijo o dobi učenja, pri tem pa je seveda težišče na vseživljenjskosti učenja; danski »program desetih točk«, ki je resolucija danskega parlamenta o razvoju izobraževanja odraslih, finski projekt razvoja izobraževanja odraslih $v$ obdobju 1975-1995, japonsko gibanje za vseživljenjsko učenje, ki ga označujejo kot »strategijo, prakso in izziv«. 